\title{
Economics of Milk Production Feeding Different Protein Supplements of Gir Cows
}

\author{
Lekhu Kumar*, R. P. Jat, Maya Jat, Om Prakash Choudhary and Vinod Kumar Kudi
}

Department of Livestock Production Management, Sri Karan Narendra Agriculture University, Jobner, Jaipur, Rajasthan, India

*Corresponding author

\section{A B S T R A C T}

Keywords

Cost, Economics, Gir cows, Gross return, Guar meal, Income, Milk production, Mustard oil cake

Article Info

Accepted:

08 December 2020 Available Online: 10 January 2021
A study was conducted on 16 lactating Gir cows, which were divided into four groups on the basis of body weight and average milk yield/day at Dairy farm (LPM Deptt.) S.K.N. College of agriculture, Jobner (Rajasthan) and subjected to four dietary treatments i.e. Wheat straw ad-lib.+ Green Lucerne $(5 \mathrm{~kg})+$ Concentrate $\left(\mathrm{T}_{1}\right), \mathrm{T}_{1}+$ Urea $75 \mathrm{~g} / \mathrm{cow}\left(\mathrm{T}_{2}\right), \mathrm{T}_{1}+$ Mustard oil cake $614 \mathrm{~g} / \mathrm{cow}\left(\mathrm{T}_{3}\right)$ and $\mathrm{T}_{1}+$ Guar meal $505 \mathrm{~g} / \mathrm{cow}\left(\mathrm{T}_{4}\right)$. The studied for their economics of milk production. Average daily milk production (litre/cow) was significantly $(\mathrm{P}<0.05)$ higher in $\mathrm{T}_{4}(7.85)$ than $\mathrm{T}_{3}(7.13), \mathrm{T}_{2}$ (7.05) and $\mathrm{T}_{1}$ (6.67). Total feed cost/litre of milk (Rs) was 29.86, 24.19, 28.29 and 25.98 in $\mathrm{T}_{1}, \mathrm{~T}_{2}, \mathrm{~T}_{3}$ and $\mathrm{T}_{4}$ groups respectively during winter season.

\section{Introduction}

Livestock is an integral part of agriculture and plays an important role in contributing to national economy. Total Milk production in the India was 187.7 million tonnes during 2019 (GOI, 2019). India is the world's largest milk producer, with 21 per cent global production. Rajasthan is ranked $2^{\text {nd }}$ in India and produces 23.6 million tonnes of milk every year. Gir is a most important milch cattle breed of India. The distribution of this breed is Gir hills and forest of Kathiawar, Junagadh, Bhavnagar, Rajkot and Amreli districts of Gujarat and also in some parts of Maharashtra and Rajasthan. The body of Gir animals is well proportioned, the head is moderately long but massive in appearance with prominent bony forehead straight and leveled back are the most the marking characters of the breed and body colour is red to white, Udder is well developed and round in Gir cattle. Cattle of this breed are most important for their tolerance to stress conditions and resistant to various tropical diseases. Nutrition plays crucial role in growth, reproduction and production of animals but the biomass resources are very 
limited and there is shortage of feed and fodder. There is a serious shortage of conventional feed resources. Hence, it is necessary to look for protein rich, nonconventional feed resources. Proper and balance feeding is essential for economic milk production to make dairy farming a successful enterprise because feed cost accounts about 75 per cent of milk production in cattle. The cost per $\mathrm{kg}$ milk can be reduced by 60 per cent and 40 per cent, respectively by feeding good quality leguminous and non-leguminous fodder (Upadhyay, 1994). Feeding is one of the most important determinants of profit in the livestock farming. Urea is non-protein nitrogen compound. Cattle and other ruminants convert urea to protein through the production of ammonia and carbon dioxide. Urea when used for treatment of straw boost the nutritional quality of straw in terms of increased nitrogen content, enhanced the palatability and digestibility.

The composition of mustard cake (MC) varies with the variety, growing conditions and processing methods. The crude protein content varies from 33-40 per cent in mustard cake. Guar Meal used in concentrate rations for lactating dairy cows. In dairy cattle, Guar meal is a highest protein containing animal feed in its group. It is having upto 50 per cent of protein with a high digesting content. Complete ration not only improves the feeding value of feed stuff but also simplifies feeding, minimizes labour and maximizes automation. The cost of feeding per litre milk production is a significant factor governing the economic viability of livestock sector which must be reduced by adopting new measures in the ration formulation. This leads to search for sources that are also easily available and economically feasible. The expected output from this study will fill the gap of the existing deficiency of knowledge to develop the best feeding strategies to be more economically efficient in dairy production.

\section{Materials and Methods}

The experiment was carried out at Dairy farm, Department of Livestock Production Management, S.K.N. College of Agriculture, Jobner (Jaipur). Sixteen lactating Gir cows were selected for the experiment. They were randomly divided into four groups of four in each group on basis of nearness in their production and body weight of cows and four dietary treatments were formulated i.e.

Wheat straw ad lib. + $5.0 \mathrm{~kg}$ Lucerne + Concentrate palleted feed $\left(\mathrm{T}_{1}\right), \mathrm{T}_{1}+$ Urea@ 75 g per cow per day $\left(\mathrm{T}_{2}\right), \mathrm{T}_{1}+$ Mustard cake @ 614 g per cow per day $\left(\mathrm{T}_{3}\right)$ and $\mathrm{T}_{1}+$ Guar meal@505 g per cow per day $\left(\mathrm{T}_{4}\right)$ and the studied for their economics of milk production feeding different protein supplements of Gir cows.

\section{Cost of feeds}

Economics of feeding under different treatment was calculated from the records of feed and by considering the procurement cost of feeds and fodder used for feeding of Gir cows. Gross return was from sale of milk from different groups of cows. The cost of Lucerne and wheat straw was Rs. 700/Qtl. and Rs. 890/Qtl. respectively, which cost of concentrate palleted Rs. 2375/Qt1, Mustard cake Rs 3500/qtl, Guar meal Rs 3910 and Urea Rs. 1000/Qtl. The milk was sold to milk window@ Rs. 42/lit. during experiment period.

\section{Statistical analysis of data}

The experiment planned with subject to analysis of variance (ANOVA) for randomized block design (RBD) and the means were tested by least significance difference. Different statistical tools such as mean, standard deviation (SD), standard error (SE) were worked out to compare the group. 


\section{Results and Discussion}

The data collected during the experimental trial were subjected to standard methods of statistical analysis and presented in this chapter in the form of tables along with the implications of the results to the economics of milk production feeding different protein supplements of Gir cows under following head.

\section{Feed cost of milk production}

The economic evaluation of feeding the experimental ration and the feed cost of per litre milk production was presented in Table 16. Total feed cost was 70,033.5, 61,385.6, $73,618.8,73,530.3$ (Rs) in $\mathrm{T}_{1}, \mathrm{~T}_{2}, \mathrm{~T}_{3}$ and $\mathrm{T}_{4}$, respectively. Income for sale of milk is Rs. $101, \quad 085.6, \quad 106,545.6, \quad 107,969.4$ and $118,893.6$ in $\mathrm{T}_{1}, \mathrm{~T}_{2}, \mathrm{~T}_{3}$ and $\mathrm{T}_{4}$ groups respectively. Lactation yield (300 days) per cow were calculate is $2007,2115,2142$ and 2358 liter in $\mathrm{T}_{1}, \mathrm{~T}_{2}, \mathrm{~T}_{3}$ and $\mathrm{T}_{4}$ groups, respectively. The feed cost per litre milk production was $29.08,24.19,28.64$ and 25.98 in $T_{1}, T_{2}, T_{3}$ and $T_{4}$, respectively. The feed cost per litre milk production was higher in group $T_{1}$ as compared to $T_{2}, T_{3}$ and $T_{4}$ in Gir cows.

Table.1 Feed cost of milk production under different treatments

\begin{tabular}{|l|c|c|c|c|}
\hline Particulars & $\mathbf{T}_{\mathbf{1}}$ & $\mathbf{T}_{\mathbf{2}}$ & $\mathbf{T}_{\mathbf{3}}$ & $\mathbf{T}_{\mathbf{4}}$ \\
\hline Total quantity of lucerne green (qt) & 18 & 18 & 18 & 18 \\
\hline Total quantity of wheat straw (qt) & 18.90 & 18.79 & 23.72 & 24.44 \\
\hline Total quantity of concentrate (qt) & 17.1 & 13.50 & 13.50 & 13.50 \\
\hline Mustard cake (qt) & - & - & 2.21 & - \\
\hline Guar meal (qt) & - & - & - & 1.82 \\
\hline Urea (Kg) & - & 27 & - & - \\
\hline Feed cost (Rs.) & 12,600 & 12,600 & 12,600 & 12,600 \\
\hline Lucerne & $16,821.00$ & $16,723.1$ & $21,110.8$ & $21,751.6$ \\
\hline Wheat straw & $40,612.5$ & $32,062.5$ & $32,062.5$ & $32,062.5$ \\
\hline Concentrate & - & - & $7,845.5$ & - \\
\hline Mustard cake & - & - & - & $7,116.2$ \\
\hline Guar meal & - & 270.0 & - & - \\
\hline Urea & $70,033.5$ & $61,385.6$ & $73,618.8$ & $73,530.3$ \\
\hline Total feed cost & 2406.8 & 2536.8 & 2570.7 & 2830.8 \\
\hline Total milk production in 90 days/ 4 cows & $101,085.6$ & $106,545.6$ & $107,969.4$ & $118,893.6$ \\
\hline Total income sale of milk (90 days) & 2007 & 2115 & 2142 & 2358 \\
\hline $\begin{array}{l}\text { Estimated milk production in (300 days) } \\
\text { lactation (litre)/ cow }\end{array}$ & & & & 7.14 \\
\hline Milk yield /cow per day (litre) & 6.69 & 7.05 & 204.50 & 204.25 \\
\hline Average daily feed cost per animal & 194.54 & 170.52 & $\mathbf{2 8 . 6 4}$ & $\mathbf{2 5 . 9 8}$ \\
\hline Feed cost /litre of milk & $\mathbf{2 9 . 0 8}$ & $\mathbf{2 4 . 1 9}$ & & \\
\hline
\end{tabular}

Cost of items- (as per college rates through tender etc.)

Green lucerne- Rs. 700/qtl

Wheat straw- Rs. 890/qtl

Concentrate- Rs. 2375/qtl

Mustard cake- Rs. 3550/qtl

Guar meal- Rs. 3910/qtl

Urea- Rs. $1000 /$ qtl

Milk rate- Rs. 42/litre 
The higher return from $\mathrm{T}_{2}$ and $\mathrm{T}_{4}$ as compared to $T_{3}$ and $T_{1}$ groups due to more milk production and lower feed cost as compared to other grous. $\mathrm{T}_{4}, \mathrm{~T}_{2}$ groups are more economical as compared to $\mathrm{T}_{3}$ and $\mathrm{T}_{1}$ groups but urea feeding is not beneficial. Mahdevi et al., (2010) pointed out that replaced protein sources with cheaper Guar meal resulted in better economic efficiency. Guar meal can be used to substitute other protein sources without any side effect reported by Turki et al., 2011. The feed cost proved that ration contained 5 per cent Guar korma improved the economic return (L.E. /H/D) recorded by Soliman et al., (2014). The cost of one kg feed for groups fed Guar meal \& CSC+GM diet were Rs. 14.48 \& $16.70 \&$ it results that Guar meal based diet was more economical than diet containing CSC+GM observed by Sharif et al., (2014). While the feed cost per kilogram milk yield was increased with increasing GKM levels showed by Wahab et al., (2016). Protein sources are more economical are reported by Boori (2018), Choudhary (2020).

Therefore, It can be concluded that feeding of Guar meal $\left(\mathrm{T}_{4}\right)$ increased the milk production as compared to Urea and Mustard oil cake feeding in Gir cows as well as increased palatability and utility of poor quality roughage (Wheat straw) and feed cost per litre milk was minimum in $\mathrm{T}_{2}$ (Urea feeding group) but not better perform on milk yield. $\mathrm{T}_{4}$ (Guar Meal feeding group) group was also more economical as well as better perform of milk production of Gir cows during winter season.

\section{Acknowledgement}

It is a great pleasure for me to express sincere and deepest sense of gratitude and indebtedness to my esteem major advisor Dr. R.P. Jat, Professor, Department of Livestock Production Management and Dean of COA,
Navgaon, Alwar, for his valuable inspiring guidance and encouragement during the course of present investigation and preparation of the manuscript. My vocabulary falls short to express heartiest regards to Sh. Mool Chand (Father), Smt. Indra Devi (Mother), Maya and Sunil (Sisters and Brother), Divya, Hitesh (Niece and Nephew), my family members and relatives without whose blessing, affection and encouragement, I could not have completed this task successfully. Last but not the least, a million thanks to almighty "Narayni Mata ji" that made it possible to complete this task and made every job a success for me.

\section{References}

Boori, SL, 2018.. Effect of different protein sources on utilization of nutrients and milk production in Gir cows. (M.Sc. Thesis, SKNAU, Jobner).

Choudhary, OP, Jat, RP, Kudi, VK and Yadav, S, 2020. Economics of milk production feeding different level of green fodder of cross-bred and Gir cows. International Journal of Chemical Studies, 8(2): 116-117.

Government of India, 2019. Basic animal husbandry statistics. Department of animal husbandry, dairying and fisheries, Ministry of Agriculture, Govt. of India, 1: 1-9.

Mahdavi, M, Torbatinejad, NM, Moslemipur, F and Samiei, R, 2010. An Evaluation of Guar Meal Replacement Potential Instead of Some Conventional Meals for Feed lot Lambs, Proceeding of Australiam Society Animal Production, 28.

Turki, IY, Elkadier, OA, Amin, ME and Hassabo, AA, 2011. Effect of Different Dietary Protein Sources on Performance of Western Baggara Cattle. Veterinary Science Research, 2(1): 8-12.

Sharif, M, Nazar, M, Sultan, JI, Bilal, MQ, 
Shahid, M and Hussain, A, 2014. Effect of replacing Cotton seed cake with guar meal on growth performance and economics in Sahiwal calves. The Journal of Animal \& Plant Sciences, 24(1): 28-32.

Soliman, MS, Okazy, AM, Salma, $\mathrm{H}$ and Hafsa, A, 2014. Effect of partially or totally replacing soybean meal by guar korma meal on sheep and cows performance milk production. Journal of Animal and Poultry Production, 5(2): $43-55$.
Upadhyay, VS, 1994. Forage resource development for increased animal productivity. In National Symp. Indian Society of Livestock Production and management, 2(5): 177-185.

Wahab, WMA, Sayed, SK, Sabek, RAM and Sobhy, HM, 2016. Effect of using Guar Korma Meal as a New Source of Protein on Productive Performance of Buffalos. Asian Journal of Animal Sciences, 10(6): 300-306.

\section{How to cite this article:}

Lekhu Kumar, R. P. Jat, Maya Jat, Om Prakash Choudhary and Vinod Kumar Kudi. 2021. Economics of Milk Production Feeding Different Protein Supplements of Gir Cows. Int.J.Curr.Microbiol.App.Sci. 10(01): 641-645. doi: https://doi.org/10.20546/ijcmas.2021.1001.078 